\title{
Socialization Concepts and Educational Management Development to Create Muslim Citizenship through Private Islamic Schools in the Southern Border Provinces of Thailand
}

\author{
CHATTHIDA YUKHONG*, THONGCHAI PHUWANATWICHIT, CHARIN MANGKHANG \\ \& ATCHARA SAROBOL ${ }^{1}$
}

\begin{abstract}
The socialization concept is a part of concept that causes the people or citizens to have the characteristics needed by the community or society. The school is an important institution of socialization through educational managements by creating a learning processes aimed at changing human behaviors and attitudes into the planned valuable and desirable directions. In addition, educational managements have created the foundations of ways of thinking, actions or interactions involving individuals and their societies. Therefore, if there is a proper education or socialization process, it will lead to quality of education and citizenship. This article originated from reviewing relevant documents by reviewing socialization concepts and educational management developments of Muslims through private Islamic schools in the southern border provinces of Thailand before 1961 until the present. It reflects the developments of socialization in order to create a Muslim citizenship and the socialization processes to be in line with the government educational management policies. But at the same time, the socialization processes also maintain the identity of the Muslims in Thailand.
\end{abstract}

Keywords: Islamic education, citizenship, educational management, socialization, Southern Thailand

The concept of socialization is a part that helps a person or citizen to achieve the characteristics that the community and society need, together with to enhance the features of a good member and creating benefits to others (Sawatdipong 1995: 5). For socialization, there will be characteristics of transmission and training a person to have a better knowledge and understanding. He can choose what was taught to behave appropriately to the community and society, which the socialization process in each institution plays an important role in molding person's personality according to social need, so as to be an important force in becoming a good member of society further by the institutions for socialization such as family, school, friend, professional group, community, religions and the media (Suparp 2006: 62).

School or educational institution, regarded as the significant institution to the educational management by creating the learning process that aims to change human behavior in a direction that has the desired value of humanity and society, including as a tool for social and political

\footnotetext{
${ }^{1}$ Chatthida Yukhong*(corresponding author), Ph.D. candidate in Education (Social Studies), Faculty of Education, Chiang Mai University, CHIANG MAI, Thailand, e-mail: chatthida_pang@hotmail.com; Thongchai Phuwanatwichit, Ph.D., assist. professor at Department of Human Relation, Faculty of Humanities, Chiang Mai University, CHIANG MAI, Thailand, email: wadasan@hotmail.com; Charin Mangkhang, Ph.D., assoc. professor at Department of Curriculum, Instruction and Learning, Faculty of Education, Chiang Mai University, CHIANG MAI, Thailand, email: charinn@hotmail.com; Atchara Sarobol, Ph.D., assist. professor at Department of Human Relation, Faculty of Humanities, Chiang Mai University, CHIANG MAI, Thailand, email: asarobol@yahoo.com.
} 
improving (Tantisoontorn 2012: 46) that can develop members of society for understanding of the cultural context, the society in which they live, and at the same time, improving the minds and feelings of those in society despite the difference in terms of religion, language, tradition and culture. It can be said that the education management is important part in building the foundation of how to think, action or interaction of things in society. Therefore, if there is a proper education or socialization process, it will lead to educational quality and citizen building.

The citizens of the society and the country will be developed through the national education system to improve and direct them according to the state policies and directions for the state citizens. The education system is an important factor in determining the direction of creating state citizen due to the ability of education to inculcate knowledge, skills and values to many students in their lives. Besides, the ability of education is to nurture the characteristics of awareness and consciousness as being the state citizens in their communications and interactions as the state citizens. (Charoenmuang 2005: 112). Therefore, the system of national education is a very important factor in leading the country towards the state development in the modern era.

Historically and culturally, the southern border provinces of Thailand are the region that has distinctive and particular characteristics in comparison with other regions in Thailand. The southern border region has its own historical background, and also a land of important Islamic learning resources. It is the region with a diverse population of ethnicity, religion and culture, and Thai Malay Muslims are the majority of the population in the region. Culturally, there is a way of life of Thai Malay Muslims different from the adherents of other religions in specific domains such as the religious practices and rituals, eating, dressing, and especially the education system (Fahrungsang 2008: 138). Although there is an education management in the three southern border provinces, there are many types of educational management in schools such as the schools managed by the Office of the Basic Education Commission (สพฐ), the schools managed by the

Private Education Promotion Committee (สช) and the schools managed the Border Patrol Police

Headquarters. But most parents trust and prefer to send their children to Islamic private schools that are directly related to their beliefs (Narongraksakhet 2006: 3).

The Office of Inspector-Inspection Area 12, Office of the Permanent Secretary of Education reported that the students enrolled in private Islamic schools are greater than those in public schools. Its proportion was about 70: 30 (Office of Bereau of Educational Development, Special Development Zone, the Southern Border Provinces, 2008: 81). The main reasons for choosing to study in the private Islamic schools are due to their belief or faith in Islam that is like a framework or guidelines to improve, nurture and create good citizenship, together with the educational management environment that is conducive to the education of the Muslims (Wisalaporn 2007: 102).

In this study, the researchers have paid attention to the educational management in the way of Islam, by focusing on the issues of the development of educational management and socialization concept leading to the creation of Muslim citizenship through Islamic private schools which are important at producing the citizens of religion and community, as well as being a guideline for the succession of the way of Islamic community that existed along with ethnic identity (Fahrungsang et al. 2008: 15). The objective of the study is to review the concept of socialization and development of education management in creating Muslim path through Islamic private schools in the southern border provinces of Thailand from the period before 1961 until the present, in order to meet the government education policy

\section{The Concept of Socialization with the Creation of Citizens}

The term "Socialization" is a concept used by sociologists, social psychologists, anthropologists, political scientists and educators to refer to the life-long inheritance process of transmission and dissemination of norm, custom and ideology, that enable people to have the skills and necessary 
characters for joining their communities and societies (Goslin 1969: 229). So socialization is considered "How to achieve continuous social and cultural relationship".

Additionally, socialization is a process that has been transmitted from a baby, where she/he starts to acquire the skills needed as a member of society, which is the most influential learning process, different from other organisms with biological behavior. Humans need social experiences to learn culture and to survive, even though cultural variances appear in the custom and behaviors of social groups. But the most basic cultural expressions, can be found on a personal level and can occur after a person has been brought up by parents, family, extended family and social networks that expand (Thomas \& James 1988: 216). The researcher has studied and collected the meaning of socialization by summarizing the meaning and concepts of many scholars as guidelines in the study as follows:

Elkin and Handel (1972: 93) mention that the socialization process is the process that is learned from society and coexistence in the same group of people to be informed of their proper rules, regulations and duties. According to Sawatdipong (2004: 127), socialization means the way individuals learn the skills, knowledge, values, motives and roles that suit their positions in the groups or societies. In sociology, socialization often focuses on the way people learn to harmonize with society. Atsakul (2010: 80) provides a means of socialization namely learning of the members in the society, both directly and indirectly, both formal and informal form, with the objective of transferring culture from one generation to another. Socialization is to develop one's personality to conform to the needs of society as well as creating an identity for oneself, to live in a society appropriately.

In addition, to review the "socialization" concept in this study, there are three significant theories explaining the socialization in various dimensions as follows:

1. In the first dimension, socialization reflects the definition and identity in each context as a result of the socialization process, both formal and informal, so that people can define themselves to be consistent and appropriate for the context. Cooley (1902) discussed the idea of looking at himself in the mirror (The looking-glass self) that the identity of the person grew out of the interaction between people in society and perception of others towards themselves. This means that individuals build their identities in relation to the perception of others towards their own and contribute to the shaping of their own according to what others perceive. The concept of the looking-glass self consists of 3 main components: (a) How we imagine that we should appear to others (b) We imagine judging our appearance from the ideas of others. (c) We develop ourselves in relation to the judgment of others towards us. Also, the concept of the looking-glass self by Cooley said that "the human mind as a society." In other words, the mental ability of the mind is a direct result of the social interaction of human beings. Humans from children begin to define themselves in the context of the socializing. For example, a child learns that his crying is a sign that he is able to stimulate the response from his parents. When children cry, they need essential things such as food as well as the attentions of their parents (Goslin 1969: 172). It is seen that the definition of identity as a result of human social interaction, and as part of the process of socialization, both formal and informal.

2. In the second dimension, socialization is presented by Mead (1934) who believes that human beings have no (self) identities from their births but because of the instructions from parents and a group of friends help children to create their identities, and make children know how "other people" are different from themselves, and how they are different from others. Enabling individuals to learn and understand how society wants them to practice by looking at reflection of other people's practices. Children begin to know themselves who they are and their own identities using languages as their mediums and symbols. As mentioned in his book entitled Mind, Self and Society, Mead calls those processes as Social Behaviorism.

3. In the third dimension, socialization reflects the improvement process through psychoanalytic theory by Freud (1905) who discussed the two socialization processes. The first socialization process refers to the process by which children grow up in society, learn the 
language, gender roles, and sexual characteristics. In this first socialization process, children learn the important concepts of psychoanalytic theory namely the concepts of unconsciousness, sexual characteristics, moral and Oedipus Knot in the second character. Socialization processes related to systems of values, religion and culture, which both of these concepts are closely related, because the socialization process is inevitably influenced by systems of culture, beliefs and social values. Moreover, Freud (2018) believed that the sexual instincts are something that humans have from birth, and they develop simultaneously with the socialization process, especially in respect to the relationship between the sexes of the babies. Children learn from their parents, family life, language, culture and tradition as well as roles and responsibilities within the society. A baby is not just a white cloth that has been added to create from the cultural society which he grows up, humans are not just recipients who have been subjected to, cultivated and nurtured to have the personalities as desired by their societies, but humans are the givers and recipients, the actors and the victims. Human activities come from the sexual instincts that grow together with the children for pursuing of their physical satisfactions (Leod 2018). The control of action will be made by parents as representatives of society or as representatives of "power" that controls the child's actions, force him not to do actions according to his own nature. In Freud's view, socialization process is a conflict that arises between the child's instinctive desire and the social control that attempts to truncate the wishes of the children and force children to behave according to the rules of Society (Kakasi 2018).

In summary, in sociological dimension, socialization is different for two reasons: First, socialization has been used in the definition of the adjustments and reliefs according to something that people appreciate and value such as reliefs, according to the expectation of the role (role expectation), comments of others or the norm and social values which such meaning appears in imagery in the Structure-functionalism. This concept looks at socialization, from the standpoint of society or social group to which people are members.

Second, socialization focuses on personal development rather than cultural transmission by providing meaning to the development process or the transformation process of a person as a result of social influence which focused on the development of "self-concept". Including the view of the person's attitude towards things, the sociological concept bureau that adheres to this view is symbolic interactions representing the conceptual concept of socialization in the dimension of the process of interaction as a result of negotiation (negotiated interactions), the alteration of the person. Outstanding characteristic of such imagery is the emphasis on symbolic interactions as a source of context of the human phenomena, mind formation, ego (self) and social structure (Sawatdipong 1995: 19). Role of the person is self-creation in line with social situation and importance of performing as a mechanism of knowing oneself and others which results in social interaction.

Thus, the emergence of identity through socialization processes does not occur in a fixed manner but has a characteristic that moves in order to conform to the situation or social context. The identity of the individual has not occurred and existed just the same way. However, there are modifications in relation to the status, roles and social context, social interaction and to make society orderly, by performing under the social rules which reflects that socialization, is an important tool in the behavior and characteristics of a person or people as social needs to lead to the growth of effective citizenship and directly affect the progress and development of the country.

\section{Development of Education Management to Create Citizens of Muslim Culture through Islamic Private Schools in the Southern Border Provinces of Thailand}

Islamic private schools are educational institutions that have evolved from traditional pondok, a Pattani Malay language, that is a modified word of the Malay language borrowed from the Arabic language "Funduk" that literally means the hotel. However generally, pondok means the student 
dormitory (Narongraksakhet 2006: 2) that provides teaching and learning without examination, evaluation and classroom. Pondok is the oldest educational institution in Southeast Asia, and an institution that has both religious and educational roles (Pitsuwan 1982: 176), has a long and important history in the southern border provinces of Thailand especially in Pattani, Yala and Narathiwat provinces. This is because most people who live in the three southernmost provinces are Thai Muslims, who are of Malay descents. Their culture and tradition are based on the teachings of Islam (Ali 2012: 57).

Pattani was the center of Islamic education since the 15th century. In addition to having Muslims in the study area, there were also Muslims in neighboring countries such as Cambodia, Malaysia and Indonesia who came to study in Pattani (Madmarn 2002: 123). The reputation of educational management in the form of pondok in Pattani has been available throughout, even though it is under the domination of Thailand. Pondok is considered the origin of Islamic private schools, an institution in the southern border provinces to have a long development with the formation of Muslim community. Teaching and learning management in the early period of pondok was conducted independently, which lacks of state support, the important objective of teaching and learning is to inherit the teachings of religion as the core.

In the past, when pondok was viewed negatively, thus causing an effort from government to provide pondok to register with public sector. In the year 1958, while the government of Field Marshal Sarit Thanarat, there was determination to improve education in the region by allowing the education sector 2 to be responsible for and overseeing education in the four southern border provinces, namely Pattani, Yala, Narathiwat and Satun, in order to plan the development of education in this area, with pondok is as an important goal to be developed (Institute of Asian Studies 2006: 143). Besides national security issues, because pondok is not registered and no supervision, the government is therefore interested and trying to improve pondok which is the educational institution of Thai people of Malay descent to come under the law of private school ( Neamkong 1995: 48).

Historically, on May 12,1961, the Ministry of Education announced the regulations of Ministry of Education regarding promoting Improvement of Pondok in the 2nd semester, 1961, which is considered pondok development to, the system of teaching and learning management or educational system management as private school teaching Islam in accordance with the Private School Act, 1954. As well as receiving support from the government in various fields and in 1982, government issued the "Private School Act 1982" allowed private schools established under the original law of Private School Act, 1954, is private school under this new act. The private school teaching Islam is changed to "Islamic Private School" (Narongraksakhet 2006: 9).

Such Islamic institution is an educational institution that is a driving force for Muslim society and an important influence throughout the school life of Thai Malay students in the area. At the elementary level, even though most Thai Malay students who are studying in government primary schools, however, because of the concentration of study about religion in public school, the parents often send their children to study basic or additional basic religion in Islamic Education Center at the mosque (Tadika). At the secondary level, most of Thai Malay students will move to study in Islamic private school, because there is a more intensive teaching of religious subjects (Hyeewang et. al. 2013: 12).

\section{Development of Socialization through Educational Management to Create Muslim Citizenship}

There is a change of development of socialization through educational management to create Muslim citizenship which has occurred all along since the year 1961 until now. In this study, the researchers focused on the issues of education to reflect the development and adaptation of educational institutions in the southern border provinces of Thailand. The researcher divided the range of educational development through the Islamic private schools in 3 phases: 


\section{Educational Management: Before 1961}

Pondok was the educational institution for Muslim Malays before the government primary school took place. Pondok was established to teach Islamic knowledge to Malays without charges, in order to follow the teachings of the Prophet that compels educators to spread knowledge they have learned to those who are uneducated (Chansongsang 2003: 43).

Pondok was established with a small cabin, and the survey of the Center for Education Development of Yala in 1978, found that the oldest pondok has been opened since 1899 (Narongraksakhet 2006:12). The efforts have been carried out by the Muslim teachers (Tokru), who have religious knowledge, by opening pondok which is considered free of charge, the teachers will earn donations or zakat. Subjects taught in pondok include Islamic faith, Islamic practices, heritage, family issues, ethics, history, reading the Koran. They are taught in in Malay and Arabic. There is an unequal amount of time for each student depending on voluntary, most are between 2-6 years.

The results of educational management before the year 1961 show the best practice of educational management, including: there is no age limit of learners, wide opportunity for everyone to learn, flexible duration of study according to the of teachers, and by the ability and the level of knowledge of the learners (Sangkhlarat 2001: 69). In addition, educational management in pondok is considered as a part of success story of Thai Malays' management.

However, the impact of education including curriculum was not clear because the courses taught in pondok depending on the aptitudes of Muslim teachers (Tokru); the pondok students were unable to transfer the subjects to other institutions; there was no standardized measurement or evaluation of teaching and learning in pondok, and the educational management system of each pondok depended on the ability of the teacher without any standard measurement from the central management (Ali 2012: 54).

\section{Educational Management: 1961-1982}

Since 1961, Ministry of Education has issued regulations that encourage all pondoks to register with the government and to teach religious subjects along with ordinary and professional subjects. Later during the year 1965-1968, the government had issued a policy that all pondoks have to transform into an Islamic private school (Narongraksakhet 2006: 12). That is, all management of educational institutions, class assignments, duration of course study and subject measurement and evaluation must be in accordance with the regulations of the Ministry of Education. This effort has led to the improvement of methods of teaching the religious, ordinary and professional subjects, preparing the certification accreditation standard of schools (Sangkhlarat 2001:74), promoting of Islamic private school and supporting the teaching and learning materials.

However, the management continued to face a considerable problems, include: (a) Lack of teachers for ordinary subjects (Ali 2012: 59). (b) Conflict in the format of teaching between religious and ordinary courses (Raweechay 1986: 33). (c) Lack of understanding between the state and local authorities, which led to the conflicts between the state educational management and the religious private schools (Sakdanarong 2018: 14). (d) A negative attitude toward Thai nation, however it was solved by the medium of education where there was an effort to combine it with the local culture (Marknuan 1982: 23) and, (e) Improving the quality of language education by studying the ordinary course in Thai language (Boonyanuwat 1982: 13). 


\section{Education Management: 1983 to Present}

The state educational management is considered an important mechanism for creating changes in the way of life of youth in the area. The government's educational management policy for Islamic private schools becomes more popular to the local people than in the past (Narongraksakhet 2006: 13). This may be due to the improvement of the curriculum and the increasing methods of teaching and learning of Islamic subject in accordance to the needs of the community.

Since 1983 the administration and the operation of many Islamic private schools have been more systematic. The educational personnel have been trained and the curriculums have been developed based on the general education (Narongraksakhet 2006: 12). As a result, the curriculums of private Islamic schools have been suited to the standard of the state modern educational system. However, the researchers found that all aspects of education especially the quality of education in Islamic private schools should be upgraded (Panagaseng 2001: 98) in comparison with the ordinary schools because the students in Islamic private schools have to study more subjects. This will affect their learning process (Fahrungsang 2014: 153).

In conclusion, the three phases of the development of educational management in creating Muslim citizenship in Thailand have faced a considerable number of challenges such as educational management, courses development, model and teaching method, measurement and evaluation process. However, one thing that remains in the hearts of personnel in managing Islamic private schools, that both Islamic teaching with Islamic principles are considered as a framework in guiding the lives of the Thai Muslim citizens. This has contributed significantly to the improvement and the production of refined way of the Thai Muslim citizens. Although Islam is the core business of Islamic private schools, the schools' curriculums have been modified to meet the challenges of the current globalization. The Muslim citizens should be more educated and have capability to apply their knowledge in their contemporary religious lives or their chosen professions. They have to adapt the changes in the society by using multi languages, advanced technology, analytical thinking skills or media literacy skills. Thus, the future development of Islamic private schools should consider the promotion and development of potential of educational personnel, development of teaching pattern and method by providing the instructors with ability to educate teachers and students in the southern border provinces of Thailand. However, such developments may not occur if there is a lack of cooperation between the group of Islamic private schools and the various government agencies related to the educational management and supervision in the southern border provinces of Thailand.

\section{References}

Ali, S. 2012. Evolution of Islamic Studies learning and teaching in private Islamic schools in the three Southern Border Provinces of Thailand. Al-Nur Journal of Graduate School 7(13): 5564.

Atsakul, S. 2010. Introducation to Sociology. Bangkok: Chulalongkorn University Press.

Boonyanuwat, M. 1982. Private Islamic Schools: Success or Failure. Rusamilae 6(Sept.-Dec.): 1-14.

Bureau of Educational Development for Special Administration Zone in the South Office of the Basic Education Commission. 2008. Educational Development for Special Administration Zone in the South Office of the Basic Education Commission Fiscal Year 2008. Bangkok: n.p.

Chansongsaeng, W. 2018. Truth Beauty and Goodness at Pondok. http://islamhouse.muslimthaipost.com/main/index.php?page=sub\& category=52\&id=1 8709. Retrieved: 5 December 2018.

Charoenmuang, T. 2005. Concepts on Citizenship. Bangkok: King Prajadhipok's Institute. 
Cooley, Charles H. 2018. Looking Glass Self and the Effect of Primary Groups. https://study.com/academy/lesson/charles-horton-cooley-theory-microsociology.html. Retrieved: 1 December 2018.

Fahrungsang, B. 2014. Multicultural Education in Southern Border Provinces. Chiang Mai: Somjainuek Press.

Fahrungsang, B. et. al. 2008. Educational Reform in Southern Border Provinces. Bangkok: National Research Council of Thailand.

Freud, S. 2018. 4 Theories of Socialisation-Explained!. http://www.yourarticlelibrary.com/sociology/4-theories-of-socialisationexplained/35088. Retrieved: 28 November 2018.

Goslin, David A. 1969. Handbook of Socialization Theory and Research. Chicago: Rand McNally. Hyeewang, F. 2013. The Significant of Model School in Pluralistic Society of the Three Southern Border Provinces of Thailand. Bangkok: National Research Council of Thailand.

Institute of Asian Studies, Chulalongkorn University. 2006. Multiculture and Education in the Southern Border Provinces: A Case Study of Pondok. Bangkok: Sriboon Computer-Printing Limited Partnership.

Kakasi. 2018. Freud Theory on Socialization. https://www.sociologylearners.com/freud-theoryon-socialization/. Retrieved: 10 December 2018.

Leod, Saul M. 2018. What are the most interesting ideas of Sigmund Freud? https://www.simplypsychology.org/Sigmund-Freud.html. Retrieved: 1 December 2018.

Madmarn, H. 2002. The Pondok and Madrasah in Patani. 2nd Printing. Bangi: Universiti Kebangsaan Malaysia.

Marknuan, C. 1982. The ways of students in private Islamic schools today. Rusamilae 6(Sept.Dec.): 18-26.

Mead, George H. 1934. Mind, Self, and Society. Chicago: The University of Chicago Press.

Narongraksakhet, I. 2006. Islamic education in the Southern Border Provinces. Indochina Studies Journal 7(1): 55-86.

Neamkong, U. 1995. Government education policy for the ethnic Malays in the Southern most provinces of Thailand (1957-1973). Thesis. Master of Arts, Silpakorn University, Bangkok.

Panakaseng, N. 2001. Educational Quality of Islamic Private Schools in the Three Southern Border Provinces. Master Thesis, M. Ed., Graduate School, Prince of Songkla University, Songkla.

Pitsuwan, S. 1982. Islam and Malay Nationalism: A Case Study of the Malay Muslims of Southern Thailand. Ph.D. Dissertation. Harvard University, Cambridge.

Raweechay, T. 1986. Directions of Private Islamic School Development. Rusamilae 9(Sept.-Dec.).

Sakdanarong, N. 2018. The Analysis of Problems of Muslims in Southern Border Provinces as Reflected in Short Stories. Retrieved from http://kb.psu.ac.th/psukb/handle/2010/6898. Retrieved: 8 December 2018.

Sangkhlarat, W. 2001. Past Present and Future Private Islamic Schools (Pondok) in the Southern Border Provinces. Masters Thesis, Educational Administration, Chiang Mai University.

Sawatdipong, P. 1995. Sociology in Daily Life: Symbolic Interactionism. Bangkok: Faculty of Sociology and Anthropology, Thammasat University.

Sawatdipong, P. 2004. Social Organization: Sociological Foundation. Bangkok: Faculty of Sociology and Anthropology, Thammasat University.

Suparp, S. 2006. Social Problem. 20th ed. Bangkok: Thai Watana Panich Press Co. Ltd.

Tantisoontorn, T. 2012. Civic Education. Bangkok: Foundation for the Promotion of Public Policy Studies.

Wisalaporn, S. 2007. Research on Educational Management Conditions in the Southern Border Provinces. Bangkok: Educational Research and Development Office, Office of the Education Council, Ministry of Education. 